
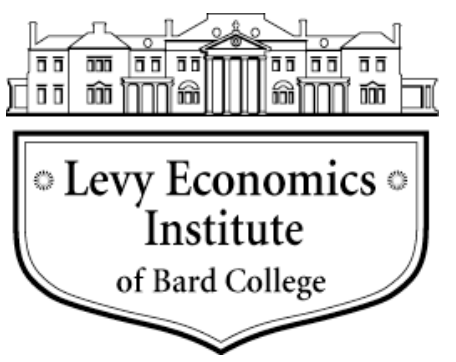

Working Paper No. 645

\title{
Quantitative Easing and Proposals for Reform of Monetary Policy Operations
}

\author{
by \\ Scott Fullwiler \\ Wartburg College \\ L. Randall Wray \\ Levy Economics Institute of Bard College
}

December 2010

The Levy Economics Institute Working Paper Collection presents research in progress by Levy Institute scholars and conference participants. The purpose of the series is to disseminate ideas to and elicit comments from academics and professionals.

Levy Economics Institute of Bard College, founded in 1986, is a nonprofit, nonpartisan, independently funded research organization devoted to public service. Through scholarship and economic research it generates viable, effective public policy responses to important economic problems that profoundly affect the quality of life in the United States and abroad.

\author{
Levy Economics Institute \\ P.O. Box 5000 \\ Annandale-on-Hudson, NY 12504-5000 \\ http://www.levyinstitute.org
}

Copyright (C) Levy Economics Institute 2010 All rights reserved 


\section{ABSTRACT}

Beyond its original mission to "furnish an elastic currency" as lender of last resort and manager of the payments system, the Federal Reserve has always been responsible (along with the Treasury) for regulating and supervising member banks. After World War II, Congress directed the Fed to pursue a dual mandate, long interpreted to mean full employment with reasonable price stability. The Fed has been left to decide how to achieve these objectives, and it has over time come to view price stability as the more important of the two. In our view, the Fed's focus on inflation fighting diverted its attention from its responsibility to regulate and supervise the financial sector, and its mandate to keep unemployment low. Its shift of priorities contributed to creation of the conditions that led to this crisis. Now in its third phase of responding to the crisis and the accompanying deep recession-so-called "quantitative easing 2," or "QE2" - the Fed is currently in the process of purchasing $\$ 600$ billion in Treasuries. Like its predecessor, QE1, QE2 is unlikely to seriously impact either of the Fed's dual objectives, however, for the following reasons: (1) additional bank reserves do not enable greater bank lending; (2) the interest rate effects are likely to be small at best given the Fed's tactical approach to QE2, while the private sector is attempting to deleverage at any rate, not borrow more; (3) purchases of Treasuries are simply an asset swap that reduce the maturity and liquidity of private sector assets but do not raise incomes of the private sector; and (4) given the reduced maturity of private sector Treasury portfolios, reduced net interest income could actually be mildly deflationary.

The most fundamental shortcoming of QE—or, in fact, of using monetary policy in general to combat the recession-is that it only "works" if it somehow induces the private sector to spend more out of current income. A much more direct approach, particularly given much-needed deleveraging by the private sector, is to target growth in after tax incomes and job creation through appropriate and sufficiently large fiscal actions. Unfortunately, stimulus efforts to date have not met these criteria, and so have mostly kept the recession from being far worse rather than enabling a significant economic recovery. Finally, while there is identical risk to the federal government whether a bailout, a loan, or an asset purchase is undertaken by the Fed or the Treasury, there have been enormous, fundamental differences in democratic accountability for the two institutions when such actions have been taken since the crisis began. Public debates surrounding the wisdom of bailouts for the auto industry, or even continuing to provide benefits to the unemployed, never took place when it came to the Fed committing trillions of dollars to the financial system — even though, again, the federal government is "on the hook" in every instance.

Keywords: Quantitative Easing; Monetary Policy; Fiscal Policy; Macroeconomic Stabilization; Interest Rates; Central Bank Operations

JEL Classifications: E42, E43, E62, E63 


\section{MISSION AND DUAL MANDATE OF THE FED}

The Federal Reserve Bank was founded in an act of Congress in 1913, with its primary directive to "furnish an elastic currency." Its mission was expanded in the aftermath of the Great Depression to include responsibility for operating monetary policy in a manner to help stabilize the economy. After World War II, Congress directed the Fed to pursue a dual mandate, long interpreted to mean full employment and reasonable price stability. The Fed has been left to decide how to implement policy to achieve these objectives and has over time experimented with a variety of methods including interest rates, reserves, and money aggregate targets. While some central banks have adopted explicit inflation targets, the Fed has argued that this would reduce its ability to respond in a flexible manner to disruptions, and would not be consistent with its dual mandate. Note also that none of the subsequent amendments to the original 1913 Act have supplanted the Fed's directive to act as lender of last resort or manager of the national payments system, providing an "elastic currency.” Finally, the Fed has always been responsible for regulating and supervising member banks_-a responsibility it shares with Treasury.

When the global financial crisis began in 2007, the Fed reacted by providing liquidity through its discount window and open market operations, later supplemented by a number of extraordinary facilities created to provide reserves as well as guarantees. The creation of various standing facilities that provided short-term credit to banks, primary dealers, and others in money markets was labeled “credit easing” by Chairman Bernanke and others. Most of the credit provided by these facilities had been wound down by late 2009.

The Treasury also intervened to provide funds and guarantees to the financial (and nonfinancial) sector, in some cases working with the Fed. Some estimates place the total amount of government loans, purchases, spending, and guarantees provided during the crisis at more than $\$ 20$ trillion-much greater than the value of the total annual production of the nation. Only a very small portion of this was explicitly approved by Congress, and much of the detail surrounding commitments made-especially those made by the Fed—is still unknown. 
While it is beyond the scope of this paper, it has become clear that inadequate regulation and supervision of financial institutions by the Fed played an important contributing role in the transformation of the financial sector that made this crisis possible. A dangerous philosophy developed over the past several decades that deregulation and self-supervision would increase market efficiency, and would allocate risk to those best able to bear it. Time after time the Fed refused to intervene to quell speculative bubbles, on the argument that the market must always be correct. This was made even worse by the Fed's cultivation of a belief that no matter what goes wrong, the Fed will never allow a "too big to fail” institution to suffer from excessively risky practice. If anything, this encouraged more risk-taking.

In recent years the Fed chose to ignore growth of systemic risk as it directed most of its intention to managing inflation expectations. Unfortunately, it also put much more weight on the inflation outcome while downplaying its other mandate to pursue full employment. This was justified_erroneously, we believe-on the argument that low inflation and low inflation expectations somehow automatically lead to robust economic growth and high employment. In summary, the Fed's growing focus on inflation-fighting seems to have diverted its attention away from its responsibility to regulate and supervise the financial sector, and its mandate to keep unemployment low. Its shift of priorities contributed to creation of those conditions that led to this crisis.

It is likely that this shift of priorities to managing inflation expectations also prevented Fed researchers from recognizing the growth of speculative and risky practices. With inflation over the past two decades remaining at moderate levels, the Fed believed its policies were working well. Each time there was a crisis, the Fed intervened to minimize disruptions. Markets coined a term - the Greenspan "put”-and elevated the Fed Chairman to "maestro" status. While many economists outside the Fed did "see it coming," and while they continually questioned the wisdom of allowing serial speculative bubbles in equity markets, real estate markets, and commodities markets, Fed researchers and policymakers mostly dismissed these warnings. Markets also frequently recognized the risks, but presumed that the Fed would bail them out of crisis. When policymakers view their role as one of ignoring systemic risk while promising rescue, 
they are effectively serving as cheerleaders for bubbles, manias, and crashes. This was a dangerous mix, bound to result in catastrophe.

In conclusion, the current crisis demonstrates the wisdom of returning the Fed to its original mission, as amended over the years by Congress:

- provision of an elastic supply of currency, acting as lender of last resort to banks when necessary to quell a liquidity crisis;

- regulation and close supervision of financial institutions, to ensure safety and soundness of the financial system; this responsibility would include use of margin requirements and other means to prevent financial institutions from fueling speculative bubbles; it also means resolving insolvent institutions rather than adopting a policy of "too big to fail” that promotes and rewards reckless behavior; and - pursuit of the dual mandates — full employment and reasonable price stability.

\section{QUANTITATIVE EASING: IMPLEMENTATION AND IMPACTS}

Chairman Bernanke has long held that a central bank can continue to provide economic stimulus even after it has pushed short-term interests near to zero, which is the lower bound. This was his recommendation for Japan, which has held rates at or near zero for a dozen years but remained mired in a downturn, with deflation of asset and consumer prices. Before joining the Fed, Professor Bernanke promoted “quantitative easing,” a policy of asset purchases by the central bank to create excess reserves in the banking system. Since excess reserves earn little or no interest, banks would be induced to make loans to earn more interest. This would, he argued, encourage spending to create the stimulus required for growth and job creation.

After the Fed had pushed the fed funds rate target close to zero ( $0-25$ basis points in December 2008), it began to pursue its first phase of quantitative easing (QE1), a new phase of monetary policy distinct from "credit easing” that had characterized the period immediately following the crisis. In March 2009 it announced plans to increase its total purchases to $\$ 1.75$ trillion. It bought housing agency securities as well as longer-term US treasuries. These purchases generally replaced the assets acquired from standing facilities 
implemented during credit easing, as most of the credits were wound down and sustained the more than doubling of the Fed's balance sheet that occurred under credit easing (see figures 9 and 10 in the appendix for growth of Fed's balance sheet). By March 2010 it had bought more than a fifth of the outstanding stock of longer-term agency debt, fixedrate agency mortgage backed securities, and Treasury securities. Purchases were handled by the New York Fed, which hired external investment managers (BlackRock, Goldman Sachs, PIMCO, Wellington, and JPMorgan were hired to provide various services).

Unlike typical open market operations, which are conducted to accommodate banks' desired reserve balances at the Fed's target rate while minimizing impacts on the prices and yields of the assets purchased, QE1 was designed to lower yields on longerterm assets. The goal is similar to that of "Operation Twist” from the early 1960s: lower the long-term interest rate relative to the short-term rate (which was already near zero when QE1 began). According to a detailed staff study by the Federal Reserve Bank of New York, the Fed's $\$ 1.75$ trillion of purchases lowered the term premium by as much as 52 basis points (that is half a percentage point; using alternative methodologies the estimated reduction falls within a range of 38 to 82 basis points) (Gagnon et al. 2010).

Chairman Bernanke has recently announced that a new round of quantitative easing (QE2) will purchase an additional $\$ 600$ billion of treasuries. A recent study by James Hamilton and Jing Wu (2010) found that $\$ 400$ billion of Fed purchases of treasuries could reduce longer-term maturities by up to 14 basis points; extrapolating from this, long-term treasury rates may be expected to fall by up to 21 basis points. Extrapolating from the New York Fed's study, QE2 could be expected to lower long-term treasury yields by about 18 basis points from current levels. However, impacts on interest rates on private debt resulting from QE2 will probably be less than either of these estimates because, unlike QE1, the Fed does not plan to buy mortgage-related debt, focusing instead on government debt. Hence, we expect longer-term rates on private borrowing (such as fixed-rate mortgages) to fall by less than the 18-21 basis points that treasury rates may be expected to fall.

While some believe that QE works by filling banks with more reserves than they want to hold, encouraging them to lend out the excess, that is clearly mistaken. First, banks do not and cannot lend reserves. Reserves are like a bank's checking account at the 
Fed and it can lend them only to another institution that is allowed to hold reserves at the Fed. Banks do lend reserves to one another in the fed funds market, but since banks already have more than a trillion dollars in excess reserves there is no need to give them more in order to encourage them to lend to one another.

The other fallacious argument is that banks need excess reserves to induce them to make loans to firms and households. There are three relevant arguments against this view. First, in normal times banks make loans and then obtain the reserves that are required for clearing or to be held against deposits. They first go to the fed funds market to borrow reserves; if there are no excess reserves in the system as a whole, this bids the fed funds rate up. Because the Fed operates with a fed funds target, it will intervene to supply the reserves banks want when the actual fed funds rate exceeds the Fed's tolerance for deviation from its target. Second, given that banks already have a trillion of excess reserves, adding more reserves will not increase their inducement to make loans-if they want to make loans, they've got enough excess reserves to cover literally trillions of dollars of new loans and deposits. Instead, because banks don't need excess reserves to make loans, suggesting that more reserve balances cause banks to make more loans is functionally equivalent to suggesting more excess reserves causes banks to reduce lending standards. Finally - and this is a point to which we return below-the US private sector is already suffering from excessive debt (indeed, that was one of the factors that contributed to the crisis). It makes little sense to encourage more lending and borrowing in a condition of national overindebtedness.

Still others believe that the “cash” created by QE2 will create more spending. That is, as the Fed purchases treasuries from households or firms, these entities now have a deposit on the asset side of their balance sheets where the treasury security once was. Of course, any individual holding a treasury that wanted instead a deposit could sell the treasury security at any time, with or without QE2. The only difference is that with QE2, the treasury may be sold at a higher price. Further, anyone holding deposits is not necessarily going to spend them, even if they were previously holding treasuries. If one's retirement savings were suddenly held only as deposits, this obviously doesn't mean that he or she will now necessarily spend what had been retirement savings. Finally, as with bank reserves, deposits do not increase banks’ abilities to create loans-a bank makes a 
loan by creating a demand deposit. Overall, adding to aggregate deposits doesn't necessarily increase spending and definitely doesn't increase the capacity of banks to lend and thereby create more deposits.

An often overlooked point is that treasuries themselves are the best form of collateral, and are routinely leveraged several times over in repurchase (repo) markets while in the process providing some of the lowest cost financing available anywhere to their owners. That is, treasuries actually facilitate additional credit creation in the financial system. In fact, repo-ing out currently held treasuries is commonly used by primary dealers to acquire funds to purchase treasuries at auction in the first place; note that the repo that finances the purchase of the treasuries itself creates the funds - and thus, again, the issuance of treasuries is not somehow reducing "cash" previously circulating in the private sector. Going in reverse order, the sale of treasuries by primary dealers to the Fed doesn't necessarily raise their "cash," since these new balances will frequently be destroyed as they are used to reduce dealers' previously incurred liabilities in the banking sector.

In sum, whether one wants to focus on the bank reserves or the deposits created by QE2, in either case QE2 does not increase “ability” of banks to create loans or for the private sector to spend that did not exist before. In both cases, the effect of QE2 is to replace within private portfolios a longer-dated treasury with shorter-term investments, which on balance reduces income received by the private sector (as we explain below). Whether or not that would increase spending will depend on whether the private sector wishes to borrow more or to reduce saving out of current income (things they can do anyway with or without QE2). Again, it makes little sense to encourage households and firms to increase debt or to reduce saving within the current context of record private sector debt.

If QE is to work, it is not through quantity but rather through price effects. Providing excess reserves serves to push the fed funds rate down. But since the Fed now pays 25 basis points on reserves, it is not possible to push the average fed funds rate below 25 basis points (since a profit-seeking bank will not lend reserves at a lower rate than the Fed pays). However, by purchasing longer-term assets the Fed can push those rates down toward the 25 basis point minimum. Competitive pressures can then lower 
other rates — such as the rate banks charge on commercial and mortgage loans. This is how QE could stimulate the economy. But as demonstrated by the New York Fed's and Hamilton and Wu's studies, the impact of QE2 on interest rates will not be large-even interest rates on US treasuries will fall only marginally. And if we presume that reduction of rates on long-term treasuries by 18-21 basis points (based on above-cited studies) were to carry through to private lending rates, the impact on private spending would be trivial. To be sure, there is a great deal of controversy about the interest rate elasticity of spending (that is, how responsive spending is to changes of the interest rate), but even taking the highest estimates and most optimistic scenario the stimulative effect of QE2 on the types of spending thought to be responsive to long-term interest rates would be insignificant.

Indeed, since the announcement of QE2, treasury rates have actually increased slightly. This again demonstrates the importance of understanding that the Fed's operations are about "price,” not "quantity.” That is, if the Fed desired a decline in treasury rates, it could only be sure to achieve this by announcing the desired new rate and standing ready to buy all treasuries offered at the corresponding price. While this might require the Fed to buy more than the announced $\$ 600$ billion size of QE2 (or it might not, in fact), it would demonstrate that the Fed clearly understood its own operations. Announcing a quantity target (\$600 billion) is not an effective way to lower yields because the Fed will pay a market-determined price to achieve that goal, and there is no guarantee that the market forces will lead to any reduction of yields with that particular quantity of treasuries purchased by the Fed.

If the Fed instead announced a price target (corresponding, say, to a yield of 2 percent on 10-year bonds) the market would quickly move yields toward that target for the simple reason that it knows the Fed will be able to purchase enough treasuries to achieve the target. The Fed's operation of QE2 is similar to its earlier operation of “credit easing” during the liquidity crisis: it focused on the quantity of reserves to be supplied (for example, through auctions) rather than on the price (set a fed funds target and then lend without limit, as a lender of last resort to all financial institutions, at that rate). Unfortunately, the Fed still has not learned how to efficiently implement monetary policy to achieve the desired result of lowering interest rates. Indeed, even the name of the 
policy, "quantitative easing," indicates that the Fed does not fully understand what it is trying to accomplish.

Finally, if we consider the possible negative impact on income and spending resulting from lower interest income received on savings, a plausible case can be made that QE2 will actually be deflationary if the policy is successful in lowering rates. Since QE2 is targeted to treasuries, its greatest impact will be on treasury yields, which provide interest income to the nongovernment sector (households, firms, not-for-profits, pension funds, and so on). Yields are already unusually low, having fallen on average by nearly 5 percentage points at the short end of the yield curve and almost 2 percentage points at the longer end of the yield curve since the financial crisis began in August 2007. This has resulted in less consumption by those who rely on government interest payments, such as retirees. Lower interest rates, in turn, encourage savers to reduce consumption to the extent that they have targeted growth of savings for retirement, college funds for their children, and so on.

In summary, it is probable that QE2 will not provide much economic stimulus; indeed we cannot be sure that QE2 will be stimulative at all, and there is even some possibility that it will reduce income and spending.

\section{QE AND ITS CRITICS}

In the previous section, we argued that the impacts of QE2 on private spending will come through effects on interest rates, and they are likely to be very low. This means that the critics of the Fed who are concerned about inflation are mistaken. While some have likened QE to “helicopter drops of money,” that clearly is not taking place. Particularly in the case of QE2, the Fed actions merely replace treasuries with reserves. While that might have a small impact on interest rates, it will not induce much spending. Further, the pressures today are overwhelmingly deflationary given the state of the economy; QE2 could even add to deflationary impacts due to the effect on interest income.

Recognizing this, some critics argue that today's policy will cause inflation in the future because QE will leave banks with massive quantities of reserves. Yet, the Fed can and will reverse course in the future if inflation pressures build. When the economy 
recovers and when there are signs of inflation, the Fed will begin to push short-term interest rates up (as it has done for decades whenever there were signs of inflation). It will also begin to drain excess reserves from banks by unwinding its own portfolio. This will be accomplished by selling its assets back into the banking system; for each bond sale it makes, it will debit bank reserves dollar-for-dollar. It can do this at a measured pace, if desired, so that these sales need not affect yields. However, if desired, the Fed can proceed more quickly, selling assets at a pace sufficient to push prices down (and yields up). The process will continue until banks hold no excess reserves.

From our discussion of interest rate elasticities above, it will be clear that we doubt such actions have a decisive impact on aggregate spending but we wish only to emphasize that the existence of more than $\$ 1$ trillion of excess reserves in the banking system will pose no challenge to policymakers when they decide to reverse QE and to raise interest rates to fight perceived inflation pressures. It should also be clear from our discussion that we are not supporters of QE, but we believe that the inflation argument is entirely erroneous. Those making the argument simply do not understand monetary operations. Finally, given that the quantity of reserves banks are holding has no impact on their ability to create loans or to otherwise finance economic activity, there is in fact little economic necessity for the Fed to drain excess reserves even if inflation pressures do build. The Fed is perfectly able to raise the federal funds rate target even in the presence of massive excess reserves, given that the target rate is now set equal to the rate paid on excess reserves banks are holding. All the Fed needs to do is to raise the rate it pays in line with the increase of its target rate, forcing market rates up on overnight funds.

There have also been reactions, especially from abroad, by those who fear that QE will cause the dollar to depreciate. Following our discussion above, there is little justification for such fear. QE will have minimal effects on long-term interest rates and on domestic spending. Hence there is little reason to believe that it will have direct impacts on capital flows or current account deficits.

To be sure, exchange rates are complexly determined and no economic models have proven successful at forecasting their movements. If QE has any impact on the value of the dollar it is likely to come through affects on expectations. We believe that expectations ultimately must be grounded in something, and if QE has as little impact on 
the US economy as we believe to be the case, then there are no grounds for believing exchange rates will change. But announcements by US policymakers can have at least temporary impacts.

We do wish that the Fed and Treasury would issue an announcement that it is not the intention of US policymakers to depreciate the dollar. We believe that all of the pressure Treasury Secretary Geithner is putting on some of our trading partners to appreciate their currencies is a mistake because it is tantamount to arguing that we want the dollar to depreciate. This, in turn, is seen by the rest of the world as a US intention to try to export its way out of its crisis - that is, intentional adoption of a modern Mercantilist policy. We do not believe that such a strategy is in the interest of the United States (it would raise the cost of imports), nor do we believe that it would be successful (it would almost certainly lead to retaliatory measures). Many historians believe that the Great Depression of the 1930s was worsened by exactly such a strategy. Policymakers must instead look to domestic policy measures to end our crisis.

Finally, a potentially negative, albeit temporary, effect of QE might be that prices in other financial markets rise even in the absence of fundamental reasons for this to occur besides an anticipated fall in treasury rates (that is, the discount rate used in valuations). This would be largely in response to anticipated increases in economic activity, or even anticipated increases in inflation that might raise commodity or equity prices (rising equity prices are usually a good thing, but the 1990s showed this isn't necessarily the case if the increase is inconsistent with underlying value). We view these effects as necessarily temporary, since as we explained in this and the previous section there are no actual transmission mechanisms for QE to directly affect the real economy (and thus affect fundamentals related to valuations) beyond a potential decrease in interest rates (which, as explained, may not even occur).

\section{RELATIVE POTENCY OF MONETARY AND FISCAL POLICY}

Over the past several decades many economists and policymakers have adopted the erroneous view that monetary policy, almost alone, can be relied upon to stabilize our economy. Further, as discussed briefly above, it was believed that monetary policy means 
macro policy - control of the money supply, interest rates, or inflation — while leaving the financial sector to self-regulation by some sort of “invisible hand" of self-interest. We believe that current events demonstrate both of these beliefs to be dangerously incorrect. It was precisely the absence of close regulation and supervision of financial markets that created the most devastating financial crisis since the 1930s (by no coincidence, the last time that policymakers relied on "free markets" in the financial sector, with virtually no use of fiscal policy to stabilize the economy). And it was the relative neglect of an active role for fiscal policy over the past generation that generated macroeconomic imbalances such as record levels of household indebtedness as borrowing substituted for jobs and income growth.

There was a long-term evolution of thinking by macroeconomists away from the sensible postwar position that "you cannot push on a string" (the idea that in the presence of pessimistic expectations, lowering interest rates through monetary ease would not encourage spending) to the view that simply by managing expectations the Fed could control the macroeconomy. Ironically, this transition occurred even as macro performance suffered, with more frequent and severe crises often caused by "bubble and bust” cycles in financial markets.

A related point is that it is important to recognize that monetary policy only “works” if it can alter the private sector's preferences for debt versus saving out of current income. That is, adjusting interest rates up or down can only affect the economy if the private sector then decides to borrow less or more. Similarly, as noted above, even if QE did work as both its proponents and some critics argue, this again would only be through encouraging the private sector to spend more out of its existing income, which again is a highly questionable strategy in a deep recession where the private sector is rationally trying to deleverage.

Consequently, we think a strong case can be made that while monetary policy is relatively impotent when it comes to stabilizing our real, productive economy, it has played a big role in pumping up asset prices that then collapse in a speculative bust. Meanwhile, our monetary policymakers have chosen to leave the financial sector largely unregulated and unsupervised. That is, in the one area over which they do have 
substantial control — regulation and supervision of financial institutions - they have refused to exercise their authority.

Instead, monetary policymakers have pursued macro policy on the highly dubious claim that they can fine-tune the economy-more than a little ironic given that their own approach is strongly grounded in a critique of so-called Keynesian "fine tuning." Yet, every tool and target that they have chosen has failed in that task-from the reserves and money targets of Chairman Volcker, to the interest rate target of Chairman Greenspan, and finally to the expectations management of Chairman Bernanke. None of these has given us sustainable growth, sustainable job creation, or sustainable rising living standards.

Indeed, incomes stopped growing for most American workers as we shifted to reliance on monetary policy and downgraded the role of fiscal policy-for more than a generation there has been no appreciable increase of median real wages. Even at business cycle peaks, tens of millions of potential workers have been left behind - unemployed or involuntarily out of the labor force; in recessions their ranks have been swelled by millions more (Pigeon and Wray 1998). Our nation’s infrastructure has been allowed to deteriorate as much of the rest of the world caught up with our living standards and, in some respects, surpassed them. While the United States has technologically advanced sectors, we have fallen behind in many areas that matter for working people—such as modern public transportation, access to decent healthcare, and high quality education for most. All of these are areas that cannot be stimulated by even well-formulated monetary policy. These are the responsibilities of fiscal policy, and they have been neglected on the unfounded belief that monetary policy, alone, is enough.

In a deep recession and financial crisis, well-formulated fiscal policy is necessary. Its first task must be to reverse job loss. While policy should help the private sector, given depressed expectations private employers cannot be expected to carry the entire burden. They will increase hiring only as economic conditions improve-no matter how many tax breaks we give them, they will not increase employment until sales increase. American households are already overburdened with debt, so we cannot wait for them to decide to increase their spending. As noted already a few times, they are rationally cutting back, trying to strengthen their balance sheets by saving. The total swing of the 
domestic private sector balance (from large deficits - spending more than income - to a substantial surplus) since the end of 2006 has been more than 10 percent of GDP (see figures 1, 2, and 3 in the appendix). That is a "demand gap” of 10 percent of GDP that must be made up by either the government sector or the external sector. If the United States were a small exporting nation it could conceivably rely on growth of exports to create the demand necessary to generate recovery. Clearly, that is not the case- - the United States is much larger than any nation and its role as provider of the international reserve currency makes it unlikely that export-led growth will bring recovery. That leaves only fiscal policy as the possible engine of growth.

There has been a lot of debate about the success of the $\$ 800+$ billion stimulus packages, with some claiming that fiscal stimulus failed to generate economic recovery. In our view, all reasonable analyses have found that it prevented the economy from falling farther than it did. While some of the spending and tax cuts may have been illconceived, the major problem with the package is that it was too small and only temporary. Indeed, as the stimulus came to an end, evidence of economic weakening has begun to appear. Nowhere is this more obvious than in the finances of state and local governments, with budget cuts and lay-offs of employees continuing. It is inconceivable that this will not have an impact on businesses and households in coming months. As public employees lose their jobs, this will have multiplied impacts on already-depressed real estate markets. America is in real danger of slipping back into recession.

What was needed was a larger and more permanent fiscal policy to deal not only with the recession but also with the areas of our economy that have long been neglected. We realize that our position goes against the grain of the current attempt to reduce the budget deficit. We note however that our currently large deficit is mostly due to collapsing tax revenue (see figure 4 in the appendix), and secondarily due to growth of transfer spending (mostly unemployment compensation) - both of which are due to the economic downturn. The budget outcome of the federal government is largely determined by economic performance: deficits rise in recession and the budget moves toward balance or even surplus in expansion (see figure 5 in the appendix). The cyclical nature of the budget is due to the automatic stabilizers rather than to discretionary policy. This is a desired feature of a national government budget-not a design flaw. Reacting to the 
normal expansion of deficits through policy to cut spending or increase taxes would be a mistake.

Most of those who are proposing that we tackle the budget deficit realize this, hence, are focused on deficit cutting once recovery is underway. Yet experience over the past several business cycle swings shows that, if anything, the budget is excessively biased toward tightening in a robust expansion. It the last two growth cycles (neither of which achieved full employment of our nation's resources) federal government tax revenue grew at an unsustainably high pace-15 percent per year and even more. This was two or three times faster than GDP. What this means is that if we were to achieve and maintain full employment, the budget deficit would quickly disappear. And that was precisely the experience during the last half of the 1990s, when a budget surplus was last achieved. We do not wish to be misinterpreted-we are not advocating a balanced budget, much less a budget surplus, as a desired outcome. We are merely arguing that there is no reason to believe that the federal budget stance is too "loose"-biased to run deficits at full employment. We think the evidence shows precisely the reverse. If the economy recovers, the deficit will rapidly shrink.

As to the longer-term deficits that supposedly will be generated by excessively generous “entitlements” (Medicare and Social Security), we think the debate has run seriously astray, funded by Pete Peterson's hedge fund billions. But that is a topic beyond the scope of this paper.

Before we move to the final section we wish to point to the similarities between our financial crisis and economic downturn and to the Japanese experience over the past two decades. Japan also had a tremendous real estate boom that then collapsed. Attached charts in the appendix (figures 6, 7, and 8) superimpose Japanese data on inflation, interest rates, and budget deficits over the same data for the United States. We have shifted the time period to make the performance over the crises comparable. What we see so far is that the United States has been tracking Japan's performance on all these variables to a remarkable degree. Japan, too, mostly relied on monetary policy. Expansion of its budget deficit was mostly due to poor economic performance. While it did try some limited stimulus packages, it always ended fiscal stimulus before the economic recovery was sustained (often by raising consumption taxes). The monetary 
policy ease never stopped the deflationary cycle, and real estate prices continue on their downward trend even today. We do not insist that Japan's twenty year-long nightmare is coming to America, but these charts should prompt policymakers to consider a more aggressive response, and one that will not exclude a greater role for sustained fiscal policy stimulus.

\section{DEMOCRATIC ACCOUNTABILITY AND TRANSPARENCY OF THE FED}

There is an additional reason to reject undue reliance on monetary policy to the exclusion of fiscal policy: those in charge of monetary policy are not subject to the same degree of democratic accountability. Further, while the Fed's actions have become more transparent since 1994 (when Representative Gonzalez caught Chairman Greenspan in a subterfuge, leading to substantial reduction of its secrecy to comply with Congressional demands), most of its deliberation remains behind closed doors. At best, it informs Congress of its decisions after the fact. We still do not know exactly what Timothy Geithner did as President of the New York Fed. He has never revealed the full extent of the promises made to private financial institutions, and we do not have a full accounting of all the purchases and deals made. Fed officials are not elected, and by design are not subject to the will of the voters. While the Fed is a creature of Congress, current law does not provide substantive control. In this section we will explore the issues raised, in particular by relying so heavily on the Fed rather than on the fiscal authorities to deal with the financial and economic crises.

Since 2007 the Federal Reserve Bank has mounted an unprecedented effort to stabilize the financial system and the national economy. Faced with the worst crisis since the Great Depression, the Fed found that traditional monetary policy-lowering interest rates and standing by as lender of last resort to the regulated banking system—was impotent in the face of collapsing asset prices and frozen financial markets. The Fed created an "alphabet soup" of new facilities to provide liquidity to markets. It worked behind the scenes to bail-out troubled institutions. It provided guarantees for private liabilities. It extended loans to foreign institutions including central banks. The Fed's on- 
balance sheet liabilities grew to $\$ 2$ trillion, while its off-balance sheet contingent promises amounted to many trillions more.

Congress and the public at large have become increasingly concerned not only about the size of these commitments but also about the shroud of secrecy surrounding actions by the Fed. For the most part, the Fed has refused requests for greater transparency. Ironically, when the crisis first hit, Treasury Secretary Paulson submitted to Congress a vague request for rescue funds that was rejected precisely because it lacked details and a mechanism to give Congress oversight on the spending. Eventually a detailed stimulus package that totaled nearly $\$ 800$ billion was approved. Yet, the Fed has spent, lent, or promised untold trillions of dollars—-far more dollars than Congress provided to the Treasury. Most of this has been negotiated behind closed doors, often at the New York Fed. The Fed's defense is that such secrecy is needed to prevent a run on troubled institutions, which would only increase the government's costs of resolution. There is, of course, a legitimate reason to fear sparking a panic.

Yet, when relative calm returned to financial markets, the Fed still resisted requests to explain its actions even ex post. This finally led Congress to call for an audit of the Fed in a nearly unanimous vote. Some in Congress are now questioning the legitimacy of the Fed's independence. In particular, given the importance of the New York Fed some are worried that it is too close to the Wall Street banks it is supposed to oversee and that it has in many cases been forced to rescue. The President of the New York Fed met frequently with top management of Wall Street institutions throughout the crisis, and reportedly pushed deals that favored one institution over another. However, like the other presidents of district banks, the President of the New York Fed is selected by the regulated banks. This led critics to call for a change to allow appointment by the President of the nation. Critics note that while the Fed has become much more open since the early 1990s, the crisis has highlighted how little oversight the Congressional and executive branches have over the Fed, and how little transparency there is even today.

There is an inherent conflict between the need for transparency and oversight when public spending is involved and the need for independence and secrecy in formulating monetary policy and in supervising regulated financial institutions. A democratic government cannot formulate its budget in secrecy. Except when it comes to 
national defense, budgetary policy must be openly debated and all spending must be subject to open audits. That is exactly what was done in the case of the fiscal stimulus package.

However, it is argued that monetary policy cannot be formulated in the open-a long and drawn out open debate by the Federal Open Market Committee about when and by how much interest rates ought to be raised would generate chaos in financial markets. Similarly, an open discussion by regulators about which financial institutions might be insolvent would guarantee a run out of their liabilities and force a government take-over. Even if these arguments are overstated and even if a bit more transparency could be allowed in such deliberations by the Fed, it is clear that the normal operations of a central bank will involve more deliberation behind closed doors than is expected of the budgetary process for government spending. Further, even if the governance of the Fed were to be substantially reformed to allow for presidential appointments of all top officials, this would not reduce the need for closed deliberations.

The question is whether the Fed should be able to commit the public purse in times of national crisis. Was it appropriate for the Fed to commit Uncle Sam to trillions of dollars of funds to bail out US financial institutions, as well as foreign institutions and governments (through repo operations with foreign central banks that lent dollars to them, exposing the Fed to default risk)? When Chairman Bernanke was grilled in Congress about whether it was "taxpayer money” that he had committed, he responded "no" it is simply entries on balance sheets. While there is an element of truth in his response, it is also highly misleading. There is no difference between a Treasury guarantee of a private liability and a Fed guarantee. If the Fed buys an asset (say, a mortgage backed security) by “crediting a balance sheet," this is no different from a Treasury purchase of an asset by “crediting a balance sheet.” The impact on Uncle Sam's balance sheet is the same in either case-it is the creation of dollars of government liabilities and leaves the government holding some asset that could carry default risk.

Note that the Fed does keep a separate balance sheet and normally runs a profit (its assets earn more than it pays on its liabilities). Profits on Fed equity above 6 percent are turned over to the Treasury. If as a result of all of its bail-out activities the Fed's profitability is diminished, Treasury's revenues will suffer. If the Fed were to accumulate 
massive losses, the Treasury would have to bail it out-with Congress budgeting for the losses. We are not projecting that this will be the case-we are merely pointing out that in practice the Fed's promises are ultimately Uncle Sam's promises, and these promises are made without Congressional approval, or even its knowledge many months after the fact.

We also are not implying that Uncle Sam would not be able to keep these promises - there is no default risk on federal government debt, and our government can afford to meet any and all commitments it makes. We are simply emphasizing that a Fed promise is ultimately a Treasury promise that carries the full faith and credit of the US government. We are not concerned with government solvency, but are only addressing the democratic accountability question: should the Fed be able to make these commitments behind closed doors, without the consent of Congress?

Some will object that there is a fundamental difference between spending by the Fed and spending by the Treasury. The Fed's actions are limited to purchasing financial assets, lending against collateral, and guaranteeing private liabilities. While the Treasury also operates some lending programs and guarantees private liabilities (for example, through the FDIC and Sallie Mae programs), and while it has purchased private equities in recent bail-outs (of GM, for example), most of its spending takes the form of transfer payments and purchases of real output. Yet, when the Treasury engages in lending or guarantees, its funds must be approved by Congress. The Fed does not face such a budgetary constraint-it can commit Uncle Sam to trillions of dollars of commitments without going to Congress.

Further, when the Treasury provides a transfer payment to a Social Security recipient, a credit to the recipient's bank account will be created (and the bank's reserves are credited by the same amount). If the Fed were to buy a private financial asset from that same retiree (let us say it is a security), the bank account would be credited in exactly the same manner (and the bank's reserves would also be credited). In the first case, Congress has approved the payment to the Social Security beneficiary; in the second case, no Congressional approval was obtained. While these two operations are likely to lead to very different outcomes (the Social Security recipient's income has risen and he/she is likely to spend the receipt; the sale of an security simply increases the seller's 
liquidity rather than his/her income and may not induce spending by the seller), so far as committing Uncle Sam they are equivalent because each leads to the creation of a bank deposit as well as bank reserves that are a government liability.

There is a difference in the impact on the federal government's reported budget, however: spending by the Treasury that is not offset by tax revenue will lead to a reported budget deficit and (normally) to an increase in the outstanding government debt stock. By contrast, purchases or loans by the Fed lead to an increase of outstanding bank reserves (an IOU of the Fed) that is not counted as part of deficit spending or as government debt (assuming there is ultimately no default on assets purchased by the Fed). (The details of all this are complicated, and there can be knock-on effects that complicate matters further.) While this could be seen as an advantage because it effectively keeps a bail-out "off the books," it comes at the cost of reduced accountability and less democratic deliberation. This is unfortunate because operationally there is no difference between a bail-out that is taken "on the books" by the Treasury (thus, following normal budgeting procedure) and one that is off the books undertaken by the Fed (thus, largely unaccountable).

Bail-outs necessarily result in winners and losers, and socialization of losses. At the end of the 1980s when it became necessary to resolve the thrift industry, Congress created an authority (the Resolution Trust Corporation) and budgeted funds for the resolution. It was recognized that losses would be socialized — with a final accounting in the neighborhood of $\$ 200$ billion. Government officials involved in the resolution were held accountable for their actions, and more than one thousand top management officers of thrifts went to prison. While undoubtedly imperfect, the resolution was properly funded, implemented, and managed to completion.

By contrast, the bail-outs so far in this much more serious crisis have been uncoordinated, mostly off-budget, and done largely in secret—and mostly by the Fed. There were exceptions, of course. There was a spirited public debate about whether government ought to rescue the auto industry. In the end, funds were budgeted, government took an equity share and an active role in decision-making, and openly picked winners and losers. Again, the rescue was imperfect but today it seems to have been successful. Whether it will still look successful a decade from now we cannot know, 
but at least we do know that Congress decided the industry was worth saving as a matter of public policy.

No such public debate occurred in the case of, say, Goldman Sachs-which was apparently saved by a series of indirect measures (for example, providing funds to AIG that were immediately and secretly passed-through to Goldman). There was never any public discussion of the need to rescue Goldman through the back-door means of providing funds to AIG-indeed, those actions were only discovered after the fact. The main public justification for rescuing financial institutions has been the supposed need to “get credit flowing again,” but if so, the bail-outs have been largely unsuccessful (and given debt loads in the private sector, encouraging lending is probably unwise in any case). Alternative methods of stimulating credit, or-better-of stimulating private spending, have hardly been discussed.

Indeed, the massive sums already provided to Wall Street (again, mostly offbudget) prove to be a tremendous barrier to formulating another stimulus package for Main Street. Even as labor markets remain moribund, as homeowners continue to face foreclosures, and as retailers face bankruptcy, Congress fears voter backlash about additional government commitments. While economists make a fine distinction between commitments made by the Fed versus those made by Treasury, voters do not. Uncle Sam is on the hook, no matter who put him there. Voters want to know what good has been accomplished by expanding the Fed's balance sheet liabilities to $\$ 2$ trillion, and by extension of Uncle Sam’s commitments by perhaps $\$ 20$ trillion through loans, guarantees, and bail-outs.

We hope that this paper will encourage policymakers to explore the following issues surrounding transparency and accountability:

1. Is there an operational difference between commitments made by the Fed and those made by the Treasury? What are the linkages between the Fed's balance sheet and the Treasury's? 
2. Are there conflicts arising between the Fed's responsibility for normal monetary policy operations and the need to operate a government safety net to deal with severe systemic crises?

3. How much transparency and accountability should the Fed's operations be exposed to? Are different levels of transparency and accountability appropriate for different kinds of operations: formulation of interest rate policy, oversight and regulation, resolving individual institutions, and rescuing an entire industry during a financial crisis?

4. Should safety-net operations during a crisis be subject to normal Congressional oversight and budgeting? Should such operations be on- or off-budget? Should extensions of government guarantees (whether by Fed or by Treasury) be subject to Congressional approval?

5. Is there any practical difference between Fed liabilities (bank notes and reserves) and Treasury liabilities (coins and bonds or bills)? If the Fed spends by "keystrokes" (crediting balance sheets, as Chairman Bernanke says), can or does the Treasury spend in the same manner?

6. Is there a limit to the Fed's ability to spend, lend, or guarantee? Is there a limit to the Treasury's ability to spend, lend, or guarantee? If so, what are those limits? And what are the consequences of increasing Fed and Treasury liabilities?

7. What can we learn from the successful resolution of the 1980s Thrift crisis that could be applicable to the current crisis? Going forward, is there a better way to handle resolutions of financial crises, putting in place a template for a government safety net to deal with systemic crises when they occur? (Note that this is a separate question from creation of a systemic regulator to attempt to prevent crises from occurring; however, Congress should explore the wisdom of separating the safety net's operation from the operations of a systemic regulator.) 
8. What should be the main focuses of the government's safety net? Possibilities include: rescuing and preserving insolvent financial institutions versus resolving them; encouraging private lending versus direct spending by government to create aggregate demand and jobs; debt relief versus protection of interests of financial institutions; minimizing budgetary costs to government versus minimizing private or social costs. 


\section{References}

Gagnon, Joseph, Matthew Raskin, Julie Remache, and Brian Sack. 2010. "Large-Scale Asset Purchases by the Fed: Did they Work?” Staff Reports No. 441, March. New York: Federal Reserve Bank of New York.

Hamilton, James D., and Jing Wu. 2010. “The Effectiveness of Alternative Monetary Policy Tools in a Zero Lower Bound Environment.” November. Available at: http://dss.ucsd.edu/ jhamilto/zlb.pdf

Pigeon, Marc-Andre, and L. Randall Wray. 1998. "Did the Clinton Rising Tide Raise all Boats?” Public Policy Brief 45. Annandale-on-Hudson, NY: Levy Economics Institute of Bard College (www.levy.org). 


\section{APPENDIX: DATA AND CHARTS}

\section{Figure 1}

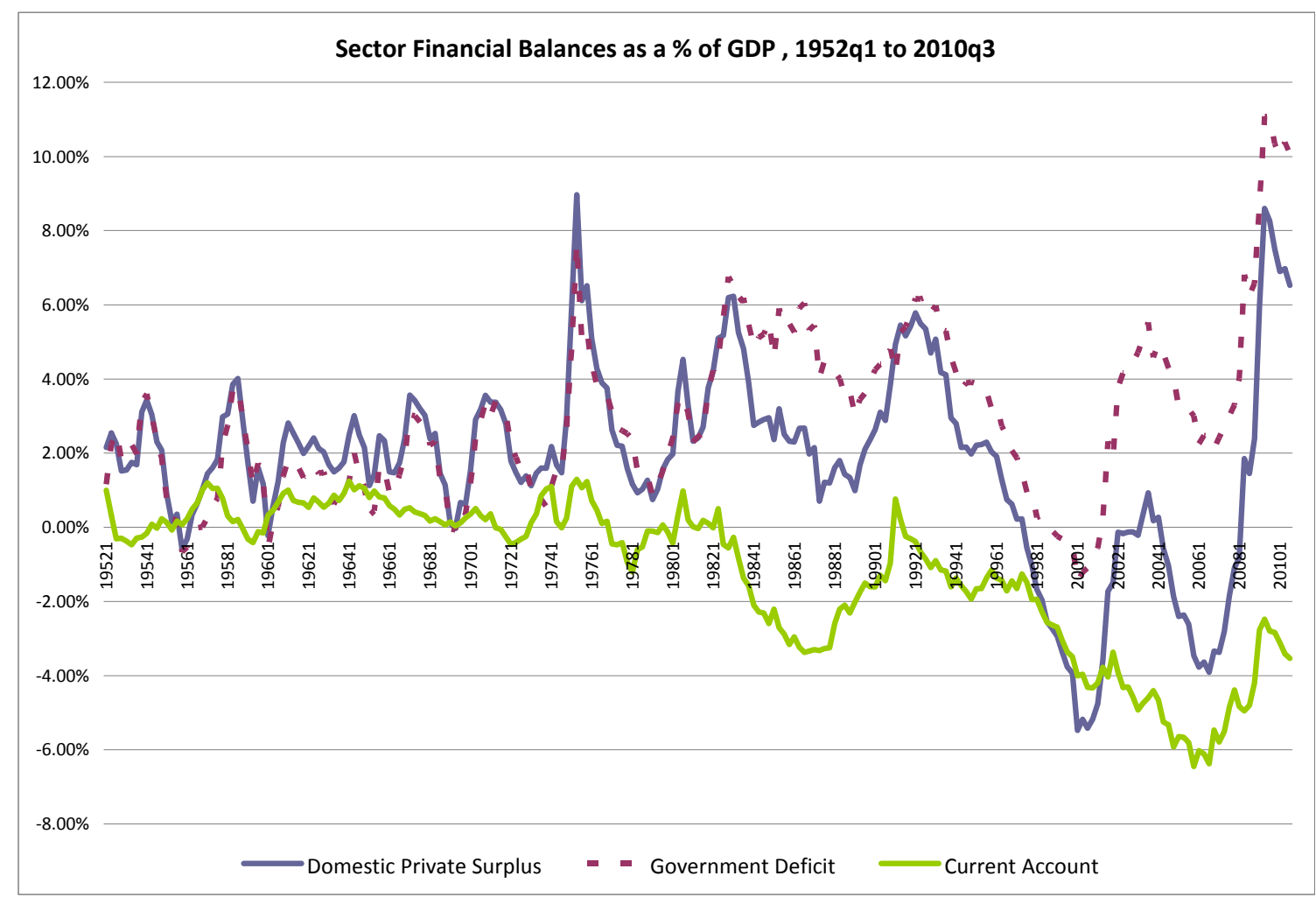

Source: National Income and Product Accounts, Flow of Funds, and author's calculations

The sector financial balances is an accounting identity:

Domestic Private Surplus $=$ Government Deficit + Current Account

In the graph above, these balances are expressed as a percent of GDP. For the United States, historically the domestic surplus or net saving (income less consumption, residential housing, and business investment spending) of households and businesses has moved in tandem with government deficits. The difference between the two, the current account balance, has largely been in a 2 to 6 percent of GDP deficit since the late 1990s. By the accounting identity, the federal government surpluses of 1998-2001 corresponded to private sector net dissaving (a deficit). The domestic private sector surplus turned negative in 1998 for the first time since brief dips below zero in the mid-1950s and 1960. This time, however, the negative net saving continued (aside from a very brief move to positive territory in the recession of the early 2000s) until the current recession. Since then, the large government deficits enabled the domestic private sector to return to a significant surplus position as the latter has attempted to repair balance sheet damage left over from the previous 12 (the beginning of negative net saving positions) to 18 years (the previous peak in the private sector's net saving consistent with post-WWII behavior was 1992). Note that since nominal sector balance data are divided by nominal GDP, the sector balances shown are in real terms. 


\section{Figure 2}

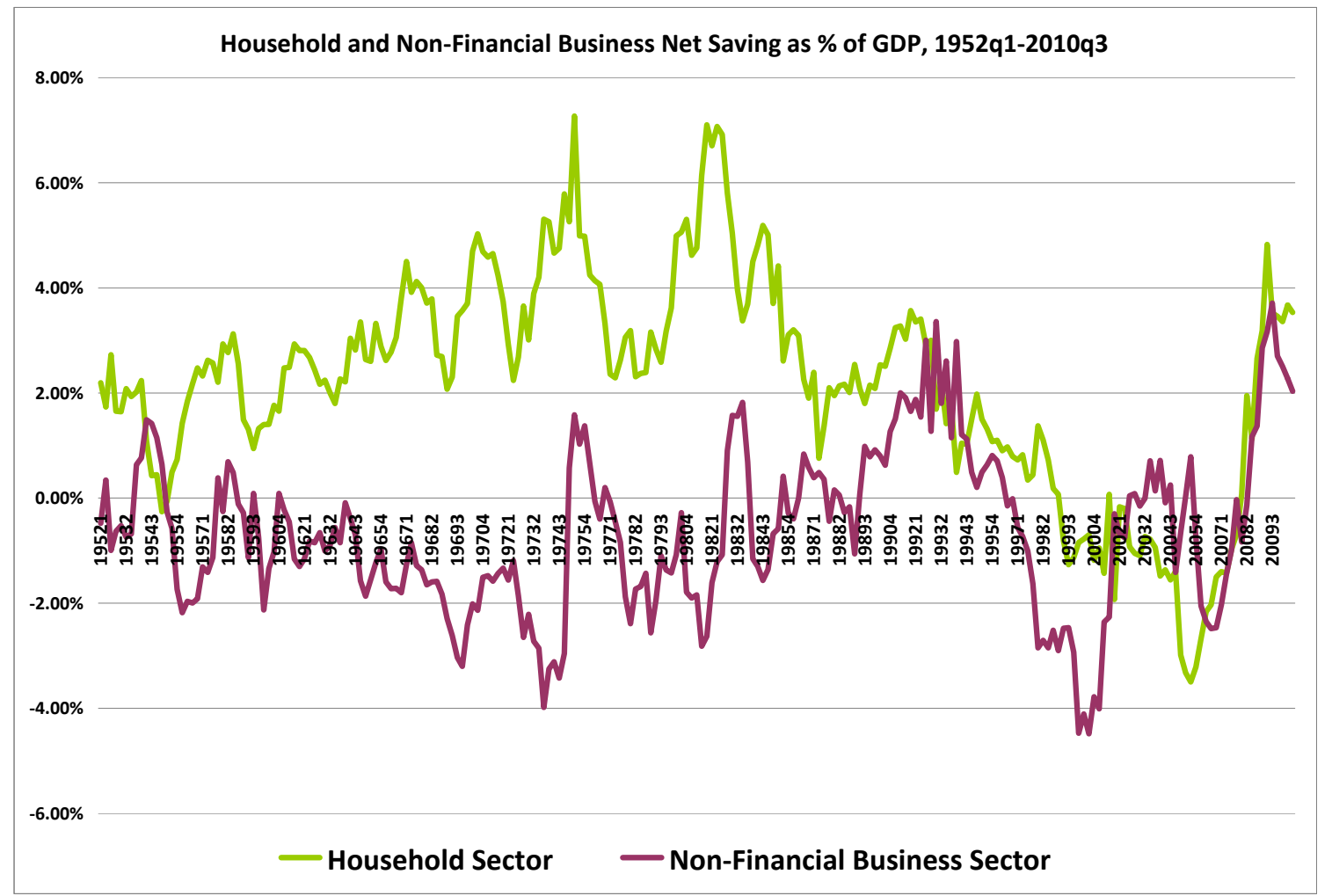

Source: National Income and Product Accounts, Flow of Funds, and author's calculations

Figure 2 breaks down the domestic private sector financial balance into the household and nonfinancial business sectors (there is also a financial business sector balance, but its behavior is of less interest here). As shown, it is the household sector financial balance that has historically been positive, while the business sector has moved between positive and negative, often depending on the state of the economy (that is, increasing during a recession and declining during an expansion as businesses accelerate borrowing to increase capacity and productivity). From the graph, it is clear that the economic expansion of the late 1990s was largely driven by a declining household balance that turned negative in 1999, and a significantly negative non-financial business sector balance that was in deficit throughout 1996-2001. Indeed, the lowest point in the business sector balance at about 4.5 percent of GDP in 2001 was lower than at any point since 1952. The 2000s expansion, as shown in the figure, was a bit more reliant on the net dissaving of the household sector, which is consistent with the residential real estate bubble-driven nature of that expansion. Both sectors have sharply increased net saving positions since 2008, with total swings in each reaching greater than 6 percent of GDP. 
Figure 3

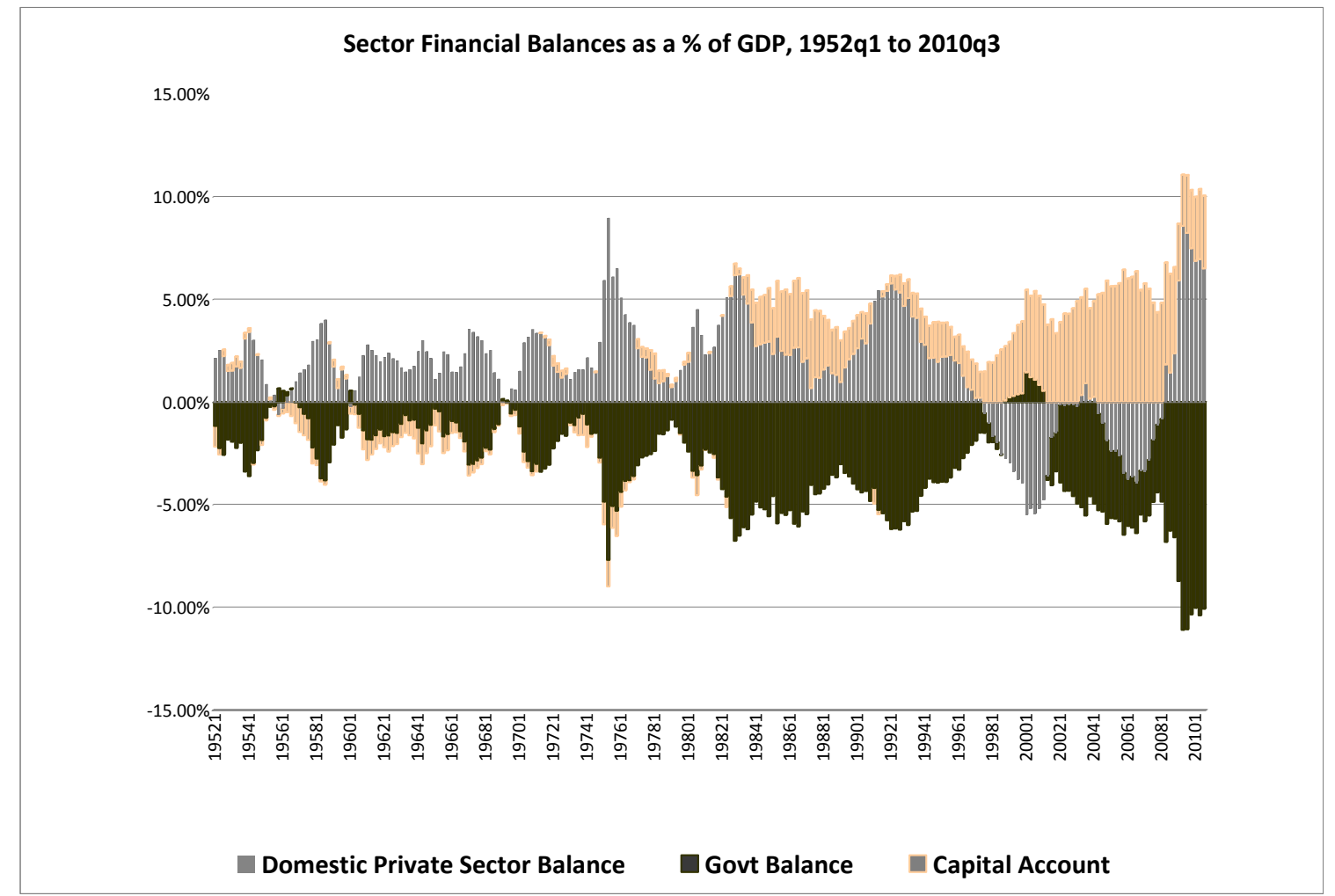

Source: National Income and Product Accounts, Flow of Funds, and author's calculations

This figure shows the sector financial balances from figure 1 . This time the government balance is shown as a mirror image of the private balance (that is, above 0 percent means a positive balance, and below 0 percent is a negative balance, whereas in figure 1 it was the opposite for the government balance). The capital account is the negative of the current account, so a positive balance there is a negative trade deficit. A few things are readily apparent in this figure. First, again, one sees that the private and government balances are nearly the reverse of one another, as the accounting identity suggests. Second, reliance on domestic private sector net dissaving during the 1998-2008 period for economic expansion to offset trade deficits and small government deficits (or surpluses during 1998-2001) is clear. This is in sharp contrast to the rest of the postWWII period that saw government deficits and trade surpluses (at least until the 1980) while the private sector was virtually always in surplus. Third, again, the return of large government deficits in 2008 enabled a return to a substantial domestic private sector surplus position. Fourth, note how throughout the postwar period, economic recessions (denoted below in figure 4) correspond to an increase in both private net saving and government deficits, while the opposite occurs during expansion. Indeed, it is this increase in private sector net saving during economic slowdowns that is in itself the recession. Reduction of private sector net saving occurs in expansion. 
Figure 4

\section{Federal Government Receipts and Expenditures (QoQ Change)}

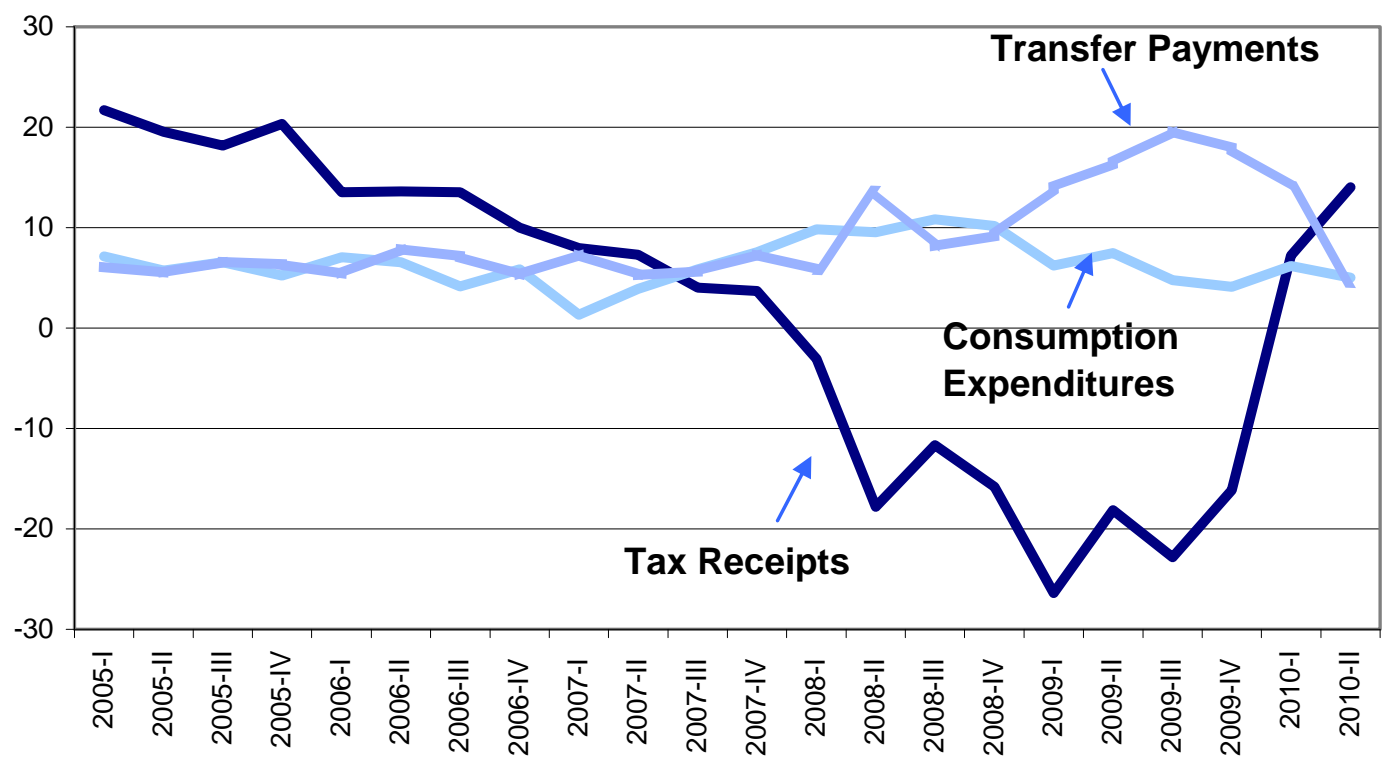

Source: Bureau of Economic Analysis and Authors' Calculations

Figure 4 shows that tax receipts grow much faster than the pace of the economy during economic expansion and contract at a brisk pace during recession. In other words, government deficits are ultimately non-discretionary. Attempts to reduce deficits, if they slow the economy (which they will unless less government spending or higher tax rates encourage the nongovernment sectors to spend more relative to current income), will slow tax revenue growth rates further, possibly (or likely) even raising deficits. This figure shows that most of the increased growth of government spending since the crisis began is due to rising spending on transfers such as unemployment compensation. Finally, this graph suggests that the budget is not too loose-even moderate economic growth such as that experienced in the mid-2000s leads to very rapid growth of tax revenues that will reduce the budget deficit. That is precisely what happened in the more robust growth after the mid-1990s, when a budget surplus was created through rapid growth of tax revenues. 
Figure 5

Federal Government Deficit/Surplus (\% of GDP) and Recessions

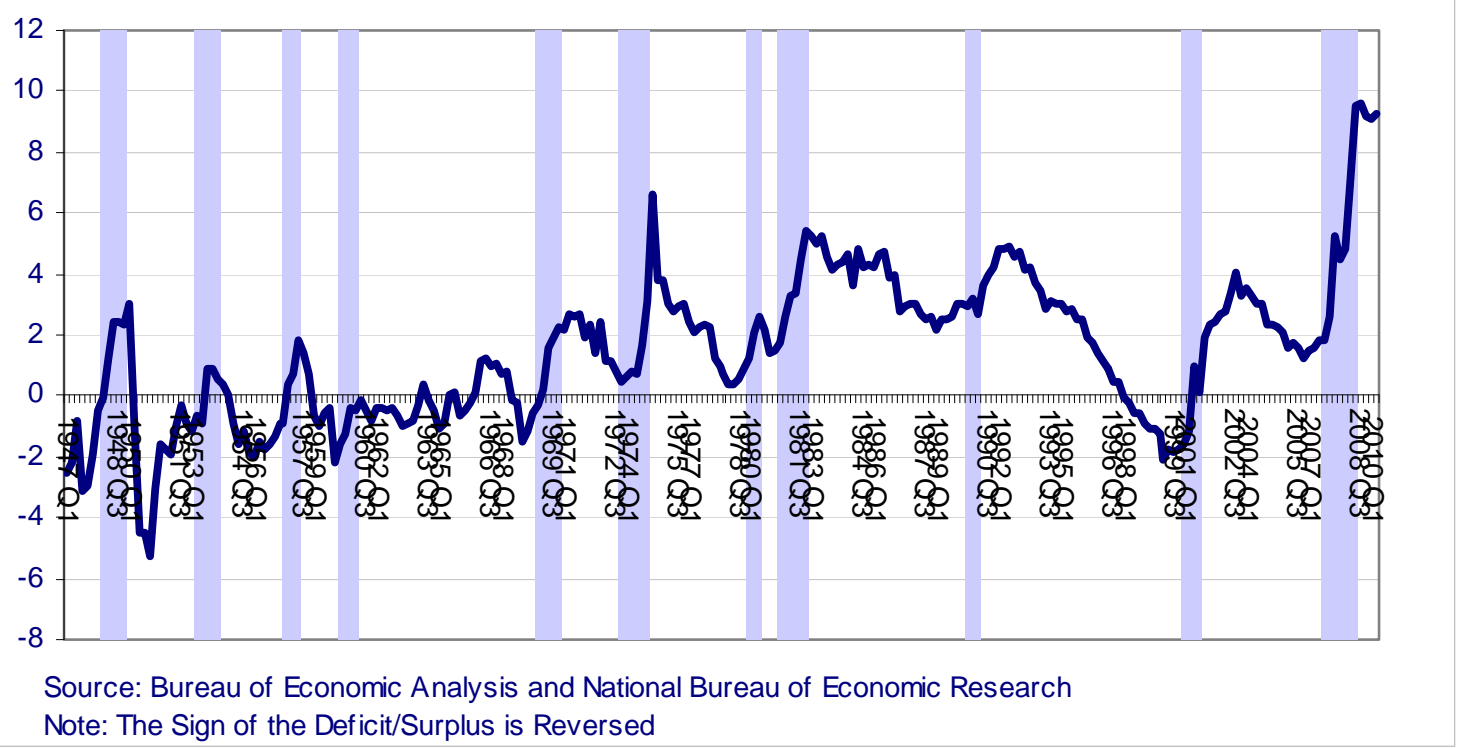

In figure 5, the sign of a year's budget deficit/surplus has been reversed. The chart shows budget deficits as a percent of GDP with periods of recession highlighted. Note that deficits rise substantially during recessions and then fall during expansions, as described for figures 1 and 3 . Again, by accounting identity, this is essentially the opposite of what is seen occurring in the domestic private sector, which reduces net saving during expansions and then increases it during recessions. And it is the government deficit that enables saving by the private sector during recessions without creating even deeper recessions. Further, this figure complements figure 4-as economic activity rises, tax revenues grow faster than both the economy and expenditures, so the budget deficit falls. The opposite occurs in a recession. Finally, note there is a very high correlation between deficit reduction (or movement toward a budget surplus) and the beginning of a recession within a few months. A tightening government budget almost always is associated with a recession that will quickly follow. That indicates that the US budget stance is not excessively loose, but rather that it may be chronically too tight. Robust economic growth creates fiscal headwinds (in the form of rapidly growing tax receipts) that then lead to recession. 


\section{Figure 6}

\section{Following Japan's Path, So Far}

In the United States, the core consumer price index, which excludes food and energy prices, rose 0.6 percent in the 12 months through October. That was the smallest 12-month gain since the government began calculating the figure in the 1950s. The chart shows the 12 -month changes in core C.P.I. for the United States and Japan, in the years before and after housing prices peaked in each country.

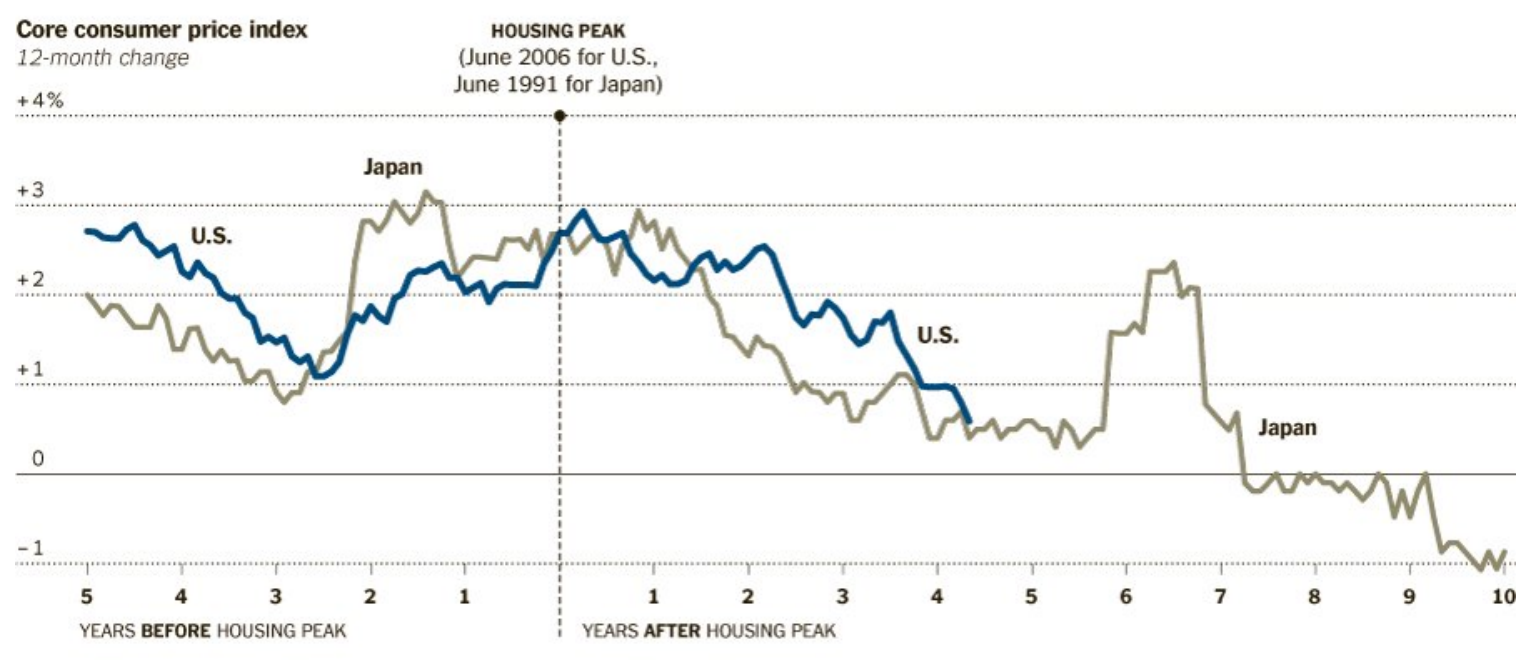

Souces: U.S. Bureau of Labor Statistics, Japanese Ministry of Internal Affairs and Communications, via Haver Analytics

Source: Floyd Norris, “After the Fed's Action, Watching Inflation Trajectory,” The New York Times, November 19, 2010. http://www.nytimes.com/2010/11/20/business/economy/20charts.html? r=2

As the text in the figure explains, the core CPI in both the United States and Japan have behaved remarkably similar pre- and post-housing peak in the respective countries. Again, this is not to suggest that the United States will necessarily have two decades of sluggish economic growth. At the same time, particularly given similar policy actions in both countries relative to the financial sector, monetary policy and stop/start fiscal policies, it is also not an irrelevant comparison. Note that the Bank of Japan carried out treasury security purchases during the first part of the 2000s far larger in size as a percent of GDP than the Fed is currently proposing. 
Figure 7

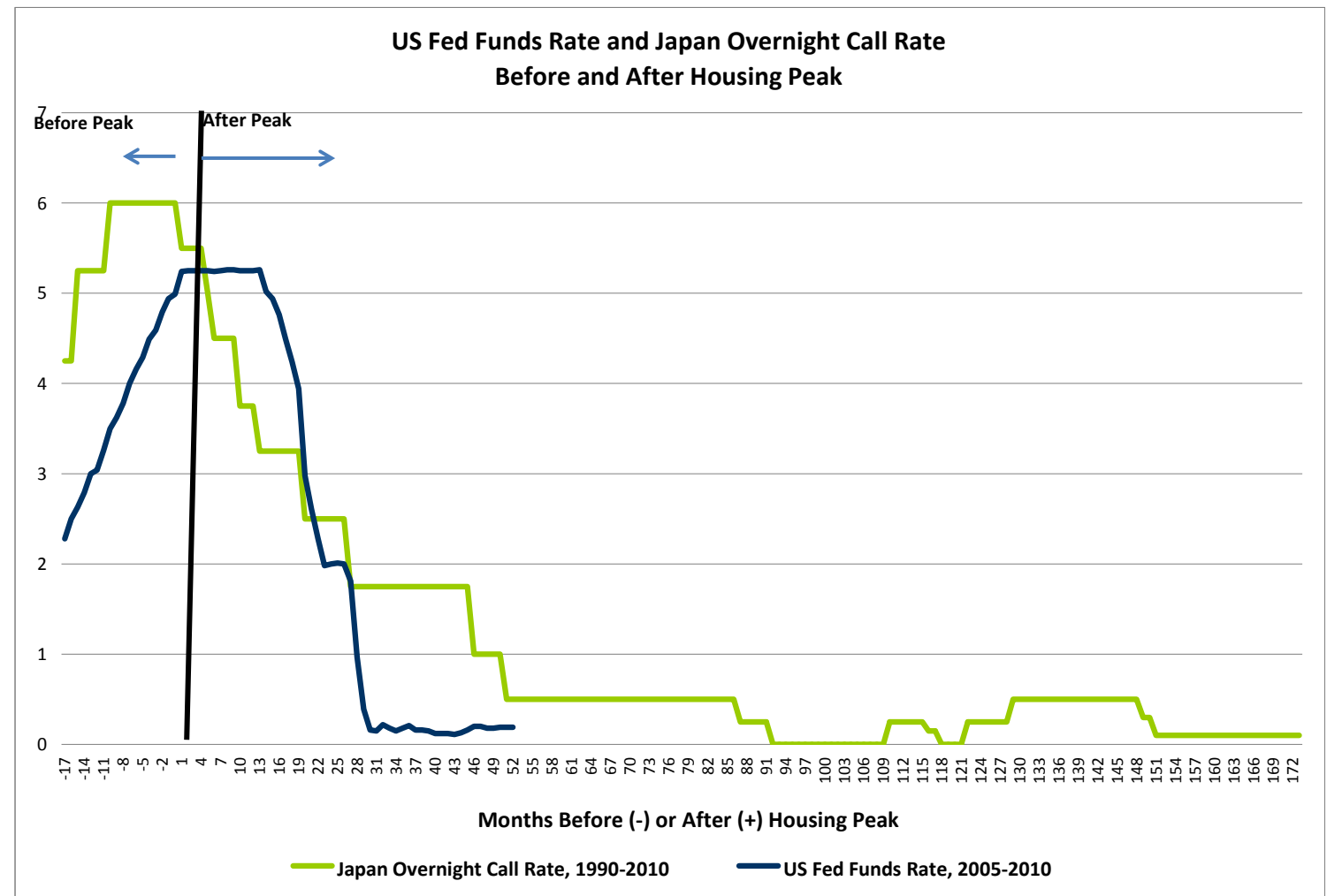

Sources: Bank of Japan and Federal Reserve Bank of St. Louis Federal Reserve Economic Database

As noted in figure 6, the monetary policy responses in Japan and the United States have been similar, with the central banks setting their respective policy target rates at very low levels within a few years of the peak in real estate markets. The similarities continue in this respect with the Fed's proposed QE2. As in figure 6, the housing peak is set at June 2006 for the United States and June 1991 for Japan. 
Figure 8

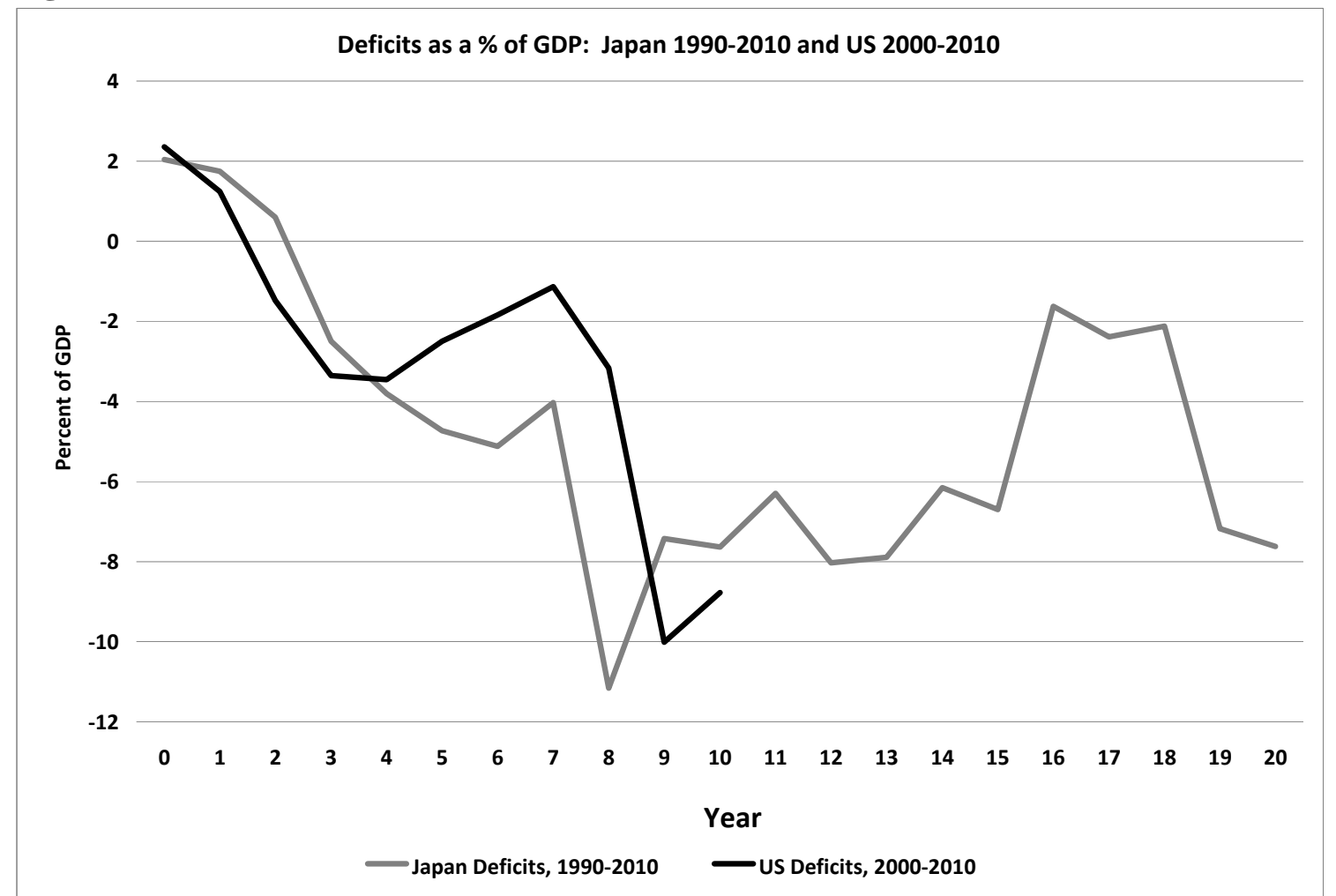

Sources: OECD and Federal Reserve Bank of St. Louis Federal Reserve Economic Database

Sluggish growth in both the United States and Japan brought larger budget deficits. Again, the size as a percent of GDP and timing of deficits in both countries has been similar. In Japan, as modest growth resumed, deficits shrank modestly and policymakers attempted to accelerate this reduction, only to have the modest growth in the economy falter, increasing the deficit yet again. In the United States now, modest growth is very modestly reducing the deficit, though the coming end of stimulus spending, potential increase and taxes, and proposed additional cuts to spending would likely reduce economic growth and raise deficits further. 
Figure 9: Fed's Liabilities

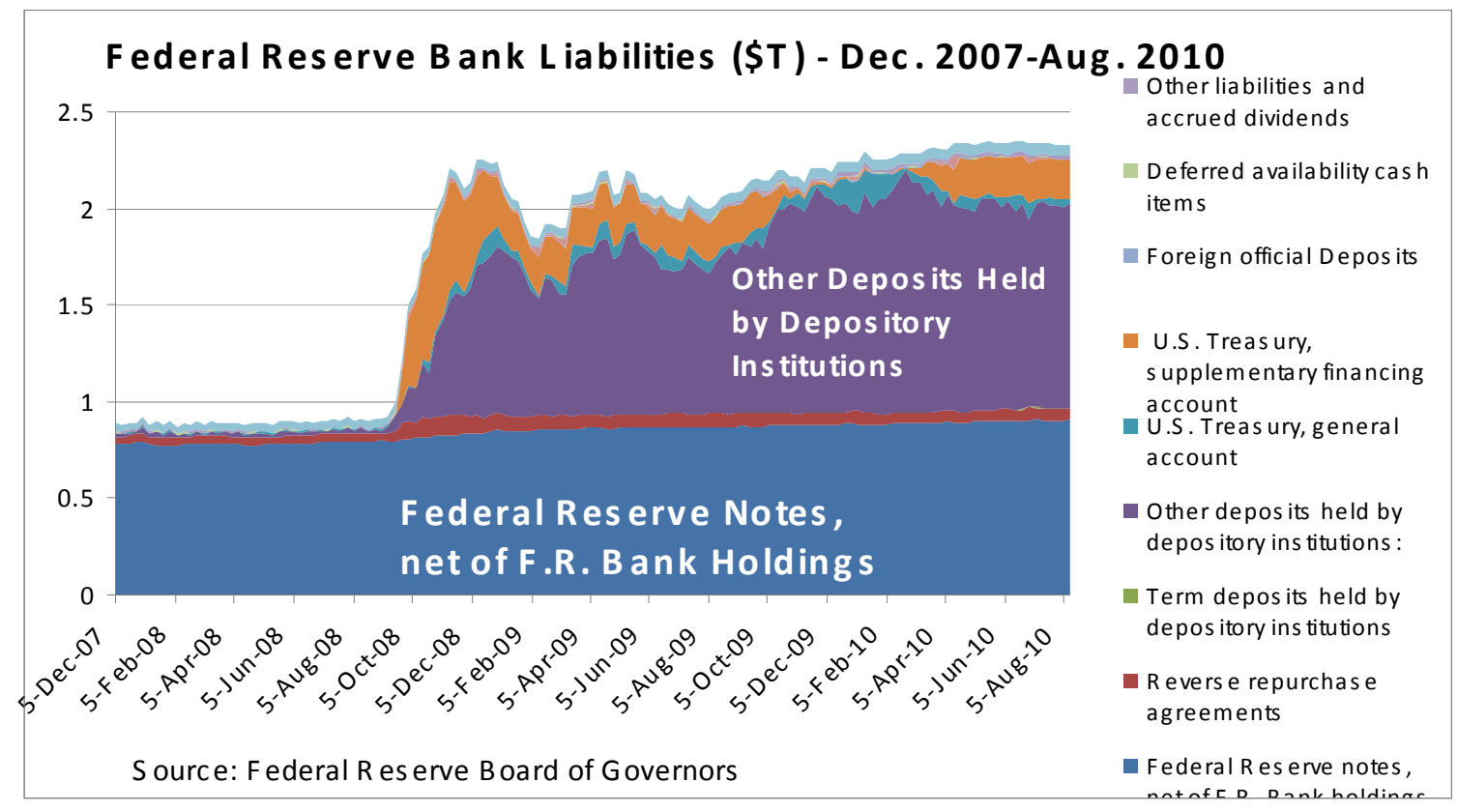

This figure shows growth of the Fed's liabilities since the crisis began-from less than $\$ 1$ trillion to nearly $\$ 2.5$ trillion. Most of the growth is in the form of reserves held by depository institutions - this growth has expanded system excess reserves from less than $\$ 2$ billion (on average) to about $\$ 1$ trillion. 
Figure 10: Fed's Assets

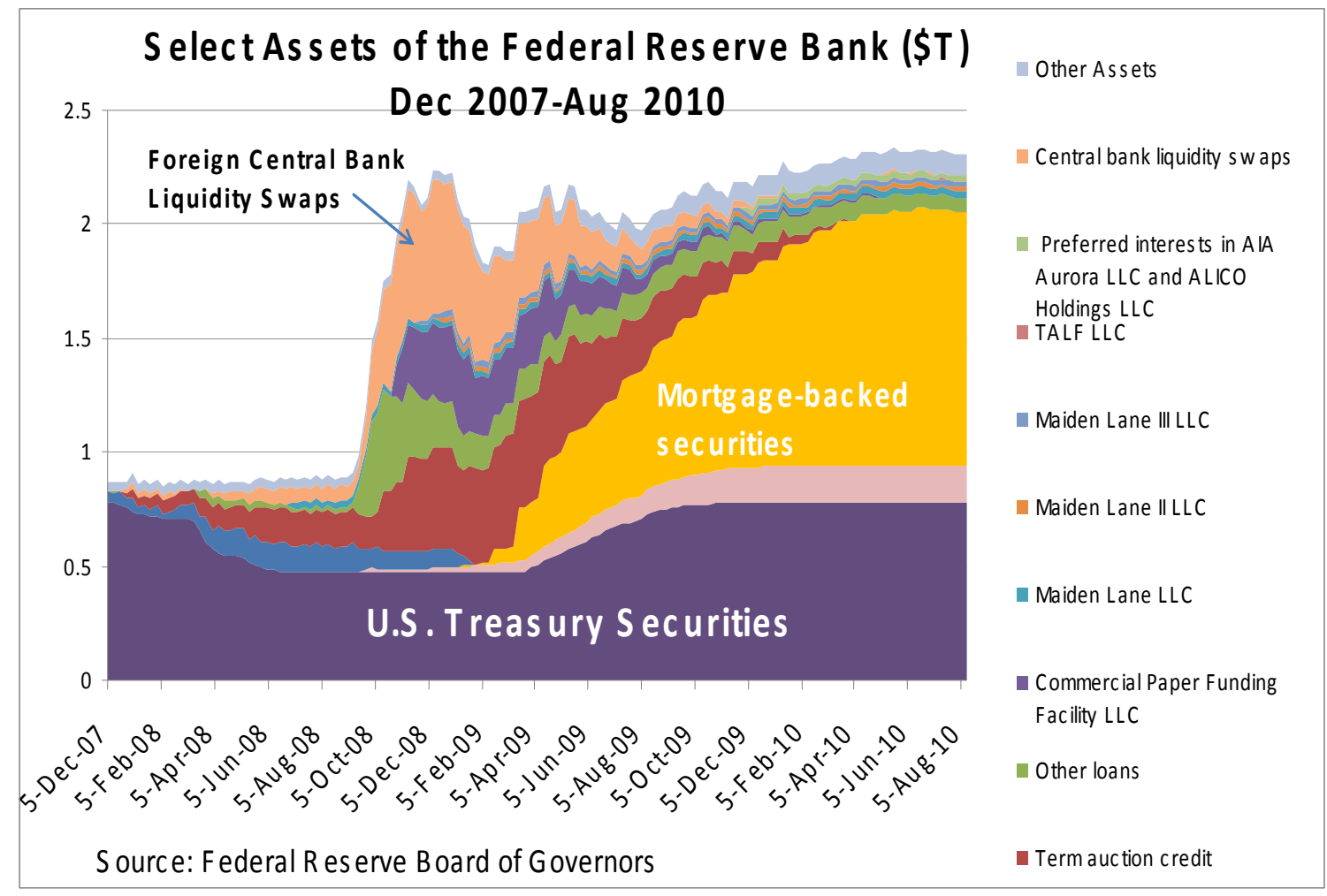

This figure shows growth of Fed assets since the crisis began, from less than $\$ 1$ trillion to almost $\$ 2.5$ trillion. In late 2008, much of the growth was in the form of lending to foreign central banks (through swaps). In the last half of 2009, the growth mostly took the form of Fed purchases of mortgage backed securities (largely through QE1). Note how the increase in mortgage backed securities effectively replaced the standing facilities as the latter winded down, while the size of the Fed's balance sheet was not significantly increased. The Fed now proposes to replace, over time, the mortgage backed securities with treasuries, and then-via QE2 - to add an additional $\$ 600$ billion in treasury securities. The net effect on the balance sheet would be the $\$ 600$ billion increase. 